\title{
Article \\ Relationship between Chemical Weathering Indices and Shear Strength of Highly and Completely Weathered Granite in South Korea
}

\author{
Seung-Hwan Lee ${ }^{1}\left(\mathbb{D}\right.$, Choong-Ki Chung ${ }^{2}$, Young-Woo Song ${ }^{3, * \mathbb{D}}$ and Sang-Inn Woo ${ }^{4}$ \\ 1 Korea Construction Standard Center, Korea Institute of Civil Engineering and Building Technology (KICT), \\ Goyang 10223, Korea; seunghwanlee@kict.re.kr \\ 2 Department of Civil and Environmental Engineering, Seoul National University, Seoul 08826, Korea; \\ geolabs@snu.ac.kr \\ 3 Institute of Construction and Environmental Engineering (ICEE), Seoul National University, \\ Seoul 08826, Korea \\ 4 Department of Civil and Environmental Engineering, Hannam University, Daejeon 34430, Korea; \\ siwoo@hnu.kr \\ * Correspondence: songyw@snu.ac.kr; Tel.: +82-10-6263-9148
}

Citation: Lee, S.-H.; Chung, C.-K.; Song, Y.-W.; Woo, S.-I. Relationship between Chemical Weathering Indices and Shear Strength of Highly and Completely Weathered Granite in South Korea. Appl. Sci. 2021, 11, 911. https://doi.org/10.3390/app11030911

Received: 27 November 2020

Accepted: 18 January 2021

Published: 20 January 2021

Publisher's Note: MDPI stays neutra with regard to jurisdictional claims in published maps and institutional affiliations.

Copyright: (c) 2021 by the authors. Licensee MDPI, Basel, Switzerland. This article is an open access article distributed under the terms and conditions of the Creative Commons Attribution (CC BY) license (https:// creativecommons.org/licenses/by/ $4.0 /)$

\begin{abstract}
In South Korea, weathered granite is widely distributed and has been used as a bearing stratum for various structures. Therefore, it is important to determine the shear strength of the weathered granite. However, it is difficult to obtain reliable shear strength parameters with laboratory tests or standard penetration test (SPT) because weathered granite is easily crushed during the sampling process, and the penetrability of SPT is not secured. On the other hand, it is well known that weathering affects the variation of geotechnical properties. Based on this concept, this study reports a correlation between the shear strength parameters and the chemical weathering indices of the weathered granite. In this study, the pressuremeter test (PMT) was adopted to determine the friction angle of the weathered granite. For the identical granite, the chemical weathering indices (Vogt's Ratio (VR), Chemical Index of Alteration (CIA), and Mobiles Index $\left(\mathrm{I}_{\mathrm{mob}}\right)$ ) were measured by $\mathrm{X}$-ray fluorescence $(\mathrm{XRF})$. An estimating model considering both site-specific characteristics and degree of weathering was used, and the CIA showed the best correlation $\left(R^{2}=0.66\right)$ with friction angle among the weathering indices. Since the ratio of measured friction angle over the predicted one was distributed in the range from 0.8 to 1.2 , it is more reasonable to predict friction angles based on CIA comparing to using the SPT-N value. It can contribute to a better estimation of friction angles of weathered granite.
\end{abstract}

Keywords: weathered granite; chemical weathering indices; shear strength parameters; pressuremeter test

\section{Introduction}

Granite is frequently encountered in South Korea, and its weathered layers are generally distributed. For general engineering purposes, their weathering grades are usually classified into six grades from fresh rock to residual soil [1]. Grade IV (highly weathered) and V (completely weathered) granite that preserves the texture and structure of the parent rock is developed in South Korea, and thus, various structures are constructed on the weathered granite; therefore, it is important to evaluate the shear strength of grade IV and $\mathrm{V}$ granite for a reasonable and rigorous design to secure the performance and safety of the structures; however, it is quite difficult to obtain reliable shear strength parameters because of the intrinsic characteristics of the weathered granite.

Kanji [2] reported that soil and rock testing devices used to evaluate geotechnical properties are not appropriate for application to grade IV and V granite, as it has intermediate strength between soils and hard rocks, which is sometimes too low or too high 
for the rock or soil testing devices. For example, for the high strength of grade IV and $\mathrm{V}$ granite, the standard penetration test (SPT) has its limitation, as the penetrability of SPT is not sufficient and typical $N$ values are greater than 50 , which is not generally recommended for interpretation. Moreover, Benoit and Howie [3] reported that SPT can lead the uncertain and insensitive site characterization for the ground with hard residual soil, soft rock, and fractured rock. In the view of laboratory tests, which requires sampling, the sample extraction process commonly destroys cores of grade IV and V granite even though the triple-core barrels are adopted.

For grade IV and V granite, the pressuremeter test (PMT) has been one of the most appropriate in situ test methods; it has been applied for both soils and unusual geomaterials such as weathered or fractured rock, cemented soil, and frozen soil [4-9]. After analysis test results from the PMT, cone penetration test (CPT), SPT, and laboratory tests (after sampling process) from 204 sites, Bustamante et al. [9] concluded that PMT is the most versatile in situ test for weathered or fragmented rocks. Additionally, Schnaid et al. [5] analyzed the friction angles of the Hong Kong granite saprolites including grade IV and V granite using the self-boring pressuremeter (SBPM) test results and Clarke and Smith [8] performed the SBPM on many types of weathered rock and presented their friction angles.

There have been research studies to figure out the relationship between the strength parameters and the chemical weathering indices for weathered rock [10-15]. Irfan [10] and Chiu and $\mathrm{Ng}$ [12] showed that there was a linear relationship between the dry density and a mobile index $\left(I_{m o b}\right)$ for Hong Kong granite. Arel and Tugrul [11] reported linear relationships between the various weathering indices and the unconfined compressive strength (UCS) for Cavusbasi granitic rocks in Turkey. Kim and Park [13] investigated the correlation between dry density, UCS, and chemical weathering indices for artificially weathered granite. However, these studies have focused on grade I-III rocks, of which an intact core sample is relatively easily obtainable. On the other hand, Lee et al. [16] estimated engineering properties of grade IV and V granite based on chemical weathering indices. Lee et al. [16] assessed that four chemical weathering indices (Vogt's ratio, modified weathering potential index, chemical index of alteration, and mobile index) and found that the their correlation with pressuremeter modulus $\left(E_{m}\right)$ shows a strong relationship $\left(\mathrm{R}^{2}>0.7\right)$. However, shear strength parameters (e.g., friction angle), which are important to a geotechnical design, have not been not considered seriously with sufficient field data.

The objectives of the present study are to evaluate the shear strength of grade IV and $\mathrm{V}$ granite measured by in situ tests and to report its correlation with various chemical weathering indices. To achieve this, this study selected three test sites with thick grade IV and V granite layers; for each site, PMTs and X-ray fluorescence (XRF) analysis for the obtained samples were conducted to evaluate the shear strength of the granite and to estimate various chemical weathering indices, respectively. Although the basic concept used in the present study is similar to the previous one [16], it is valuable to estimate the shear strength parameters based on the chemical weathering indices with additional data.

\section{Test Sites}

Three sites (A, G, and S), where the weathered granite layer was thickly developed, in the mid-western part of South Korea were selected based on the geological map of South Korea provided by the Korea Institute of Geoscience and Mineral Resources (KIGAM) and a review of many site investigations was performed previously near the area (Figure 1). 


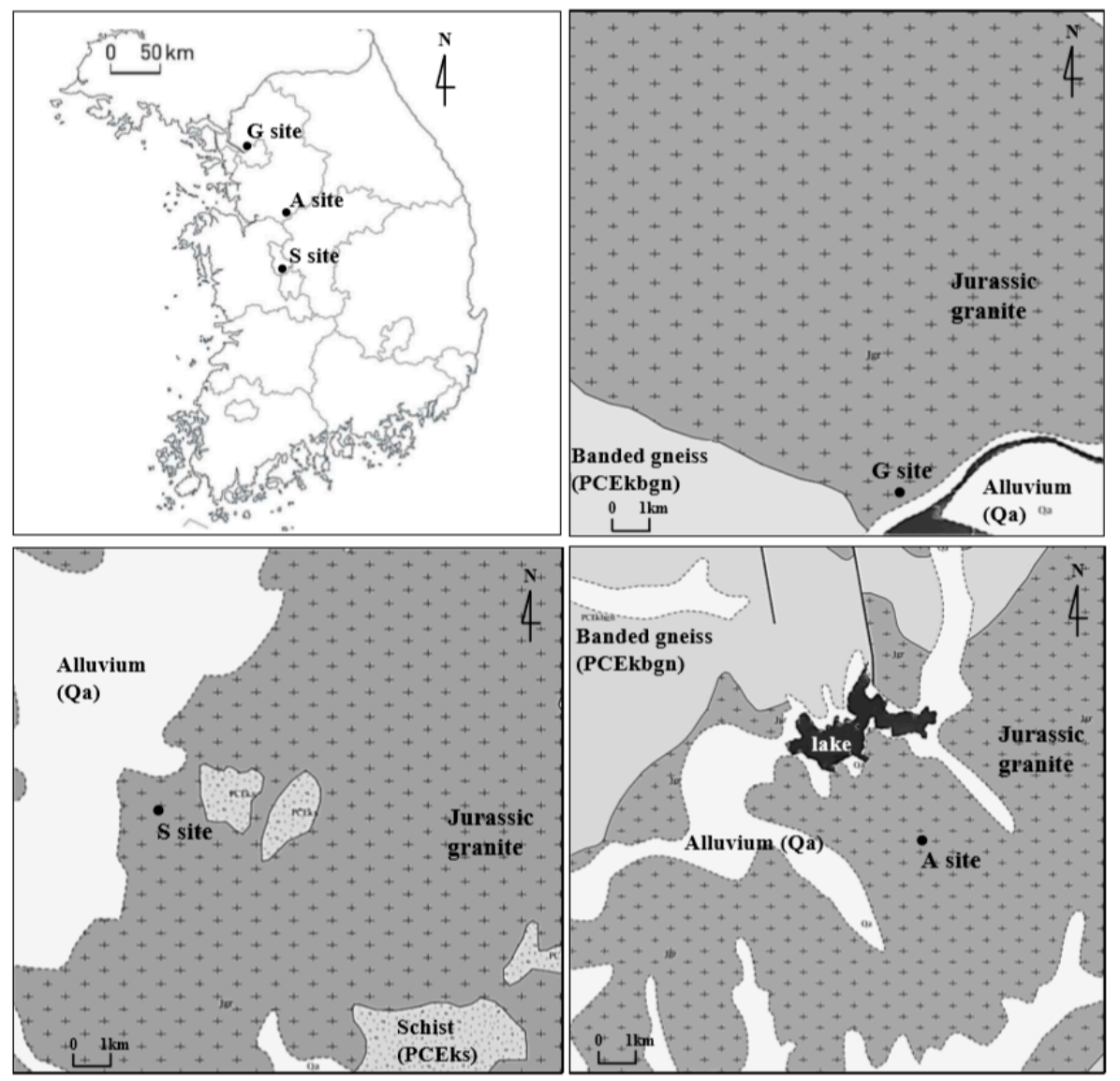

Figure 1. Locations and geological maps of test sites.

Borehole investigations to determine the composition of the subsurface were performed with SPT at all the test sites, and once SPT was refused, rock cores were retrieved with a triple-core barrel; it is regarded as SPT is not acceptable when further penetration was not observed in spite of 10 successive blows [17]. The boundary between grade VI (residual soil) and grade V granite was determined based on the SPT-N value (50 blows $/ 10 \mathrm{~cm}$ ) [18], grade III and IV granite layers were distinguished based on the core sample conditions comparing with the criterion of weathering grade [1].

Figure 2 presents the results of borehole investigations, including subsurface layer compositions and SPT-N values. Grade IV and V granite layers (A site: $19 \mathrm{~m}, \mathrm{G}$ site: $13 \mathrm{~m}$, S site: $18 \mathrm{~m}$ ), which is the target geo-material, were developed at all the test sites. Therefore, many PMTs were performed, and the samples obtained from the depth, where PMTs were to be conducted, can be analyzed by XRF. The results of PMTs and XRF are used to investigate the relationship between shear strength characteristics and chemical weathering indices of grade IV and $\mathrm{V}$ granite. 


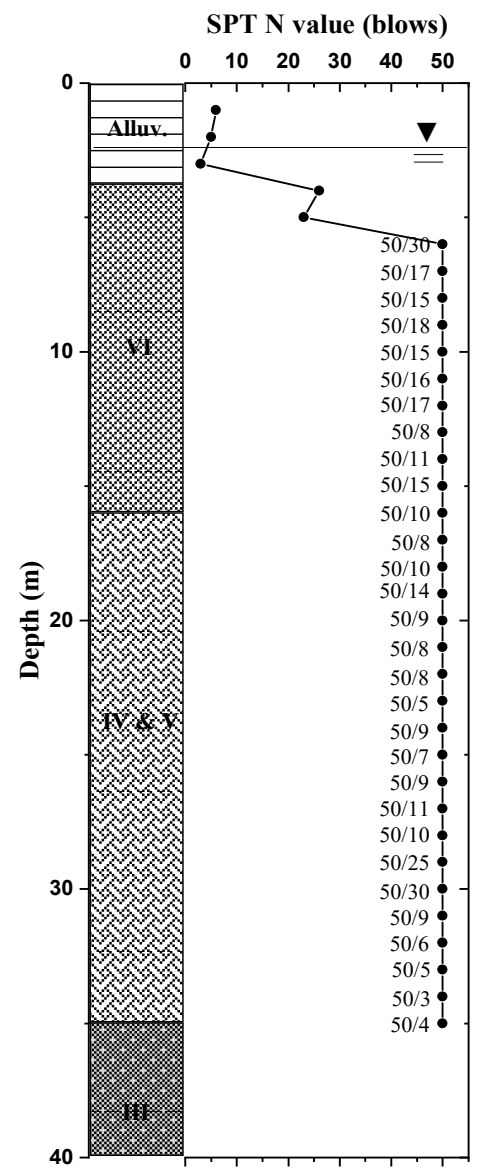

(a)
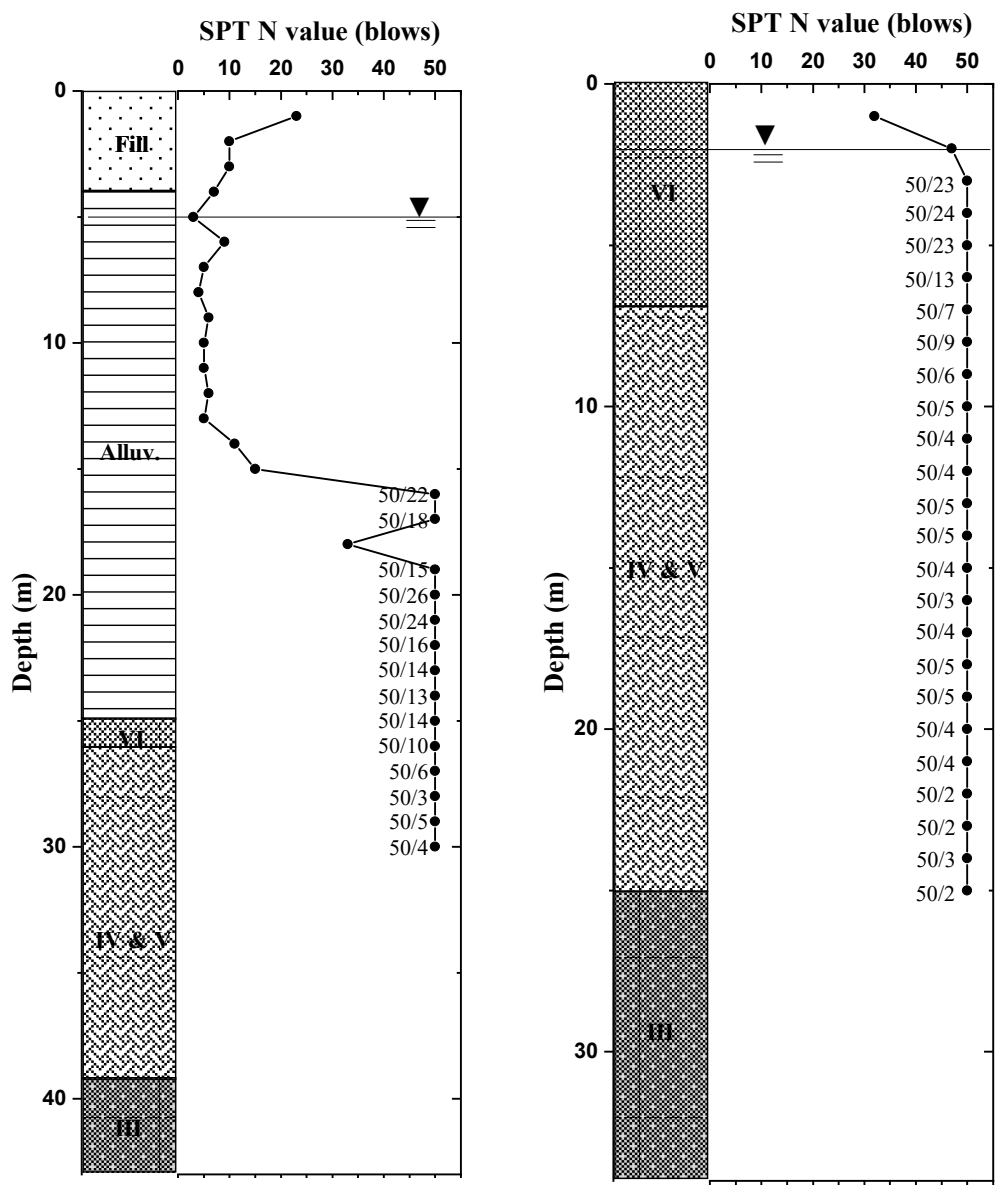

(b)

(c)

Figure 2. Boring logs of test sites: (a) A site; (b) G site; (c) S site.

\section{Test Program and Procedures}

\subsection{Pressuremeter Tests (PMTs)}

PMTs (Elastometer-2 made by Oyo Corp.) were performed to measure the borehole radius with the applied pressure. A typical pressure-borehole radius curve was divided into three steps of behavior (Figure 3a): a non-contact and disturbed zone, a pseudo-elastic zone, and a plastic zone. The pressuremeter modulus $\left(E_{m}\right)$ and limit pressure $\left(P_{L}\right)$ are representative geotechnical properties that can be obtained by interpreting the pressureborehole radius curve. $E_{m}$, which can be obtained from the pseudo-elastic part of the pressure-borehole radius curve, as shown in Figure $3 a$, has been widely used to evaluate the in situ stiffness of geo-materials since Louis Menard developed the pressuremeter, but $E_{m}$ is outside the scope of the present study.

$P_{L}$ is the pressure when the volume of probe is same to the original borehole cavity volume, and it is usually not obtained during the PMT because of the limitations of the test apparatus, insufficient pressure capacity and deformation range, and the risk of probe membrane burst. Therefore, $P_{L}$ is interpreted by extrapolating the PMT test results; Figure $3 b$ shows one of the extrapolation methods suggested by American society for testing and materials (ASTM) D4719 [19] used in this study. 


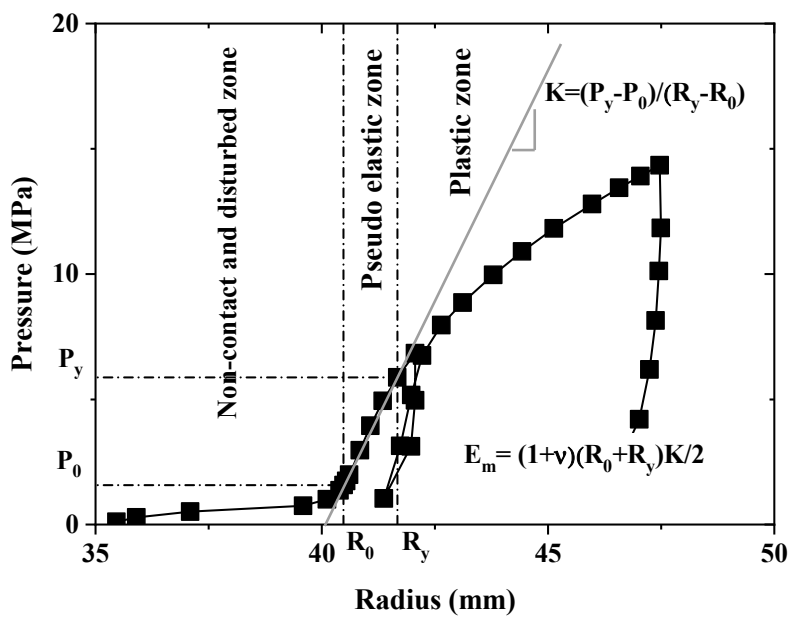

(a)

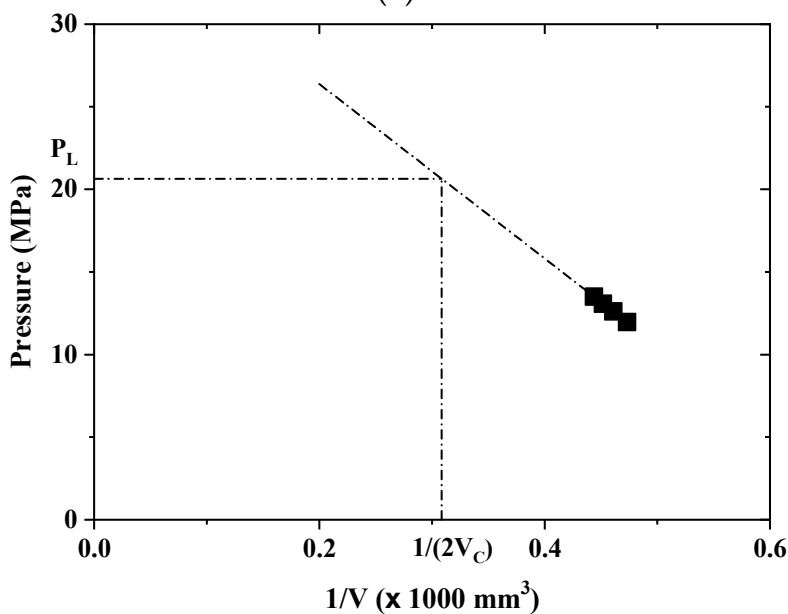

(b)

Figure 3. Interpretation of pressuremeter test (PMT) curve: (a) pressuremeter modulus $\left(E_{m}\right)$; (b) limit pressure $\left(P_{L}\right)$.

The borehole for performing PMTs was drilled with $1 \mathrm{~m}$ spacing from the borehole for investigating the subsurface composition in each test site, which described in Section 2: "Test sites". To observe the variation in the shear strength parameters of grade V and IV granite with its degree of weathering, many PMTs (37 times) were performed with a depth spacing of approximately $2 \mathrm{~m}$ from the grade VI to III granite layer in every test site. Shear strength parameters from grade VI to III granite at each test site were obtained using $P_{L}$ (see Section 4.1), and its relationship with chemical weathering indices was also analyzed. The details of the analysis are presented in the "Test results" section of the present study.

\subsection{Sampling and Geochemical Analysis}

Grade VI to III granite samples at every test site were continuously retrieved from the borehole before performing PMTs using a triple-core barrel to minimize sample disturbance (Figure 4), and XRF analysis was conducted for the retrieved samples to evaluate the degree of weathering. The fused glass beads of the fine powder samples were prepared, and a wavelength dispersive (WD) X-ray fluorescence spectrometer (XRF-1700; Shimadzu, Japan) at The National Center for Inter-University Research Facilities (NCIRF) was used under the conditions of $40 \mathrm{kV}$ and $95 \mathrm{~mA}$; the XRF-1700 supports $20-60 \mathrm{kV}$ of accelerating voltage and 5-140 mA of X-ray current, respectively, and it can detect a material content with a range from $10 \mathrm{ppm}$. The weight percentage of major oxides in the samples was obtained as the result of XRF analysis and was transferred to the molecular ratio to calculate the chemical weathering indices, which indicate the extent to which the samples were 
weathered. Several previous studies for estimating the degree of weathering based on chemical weathering indices have shown that a particular chemical weathering index composed of alkali and alkaline oxides appropriately indicates the weathering intensity of granite because the oxides decrease with weathering $[12,13,16,20]$. In addition, among various chemical weathering indices, the indices based on a group of mobile oxides and immobile oxides are more appropriate for characterizing the weathering [21,22]. Therefore, in this study, the four chemical weathering indices were selected. The indices and their ideal tendency with the degree of weathering are presented in Table 1.

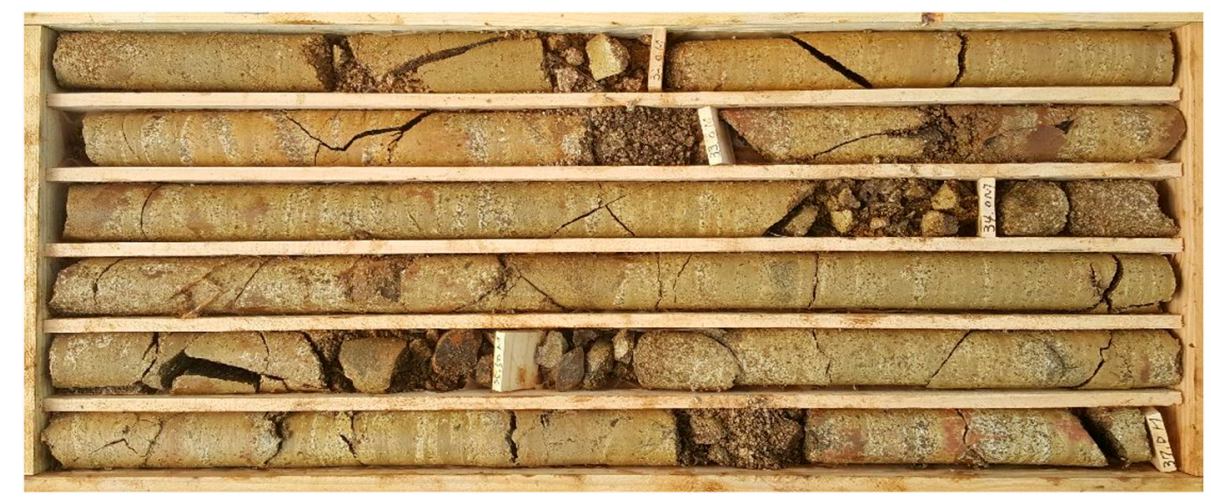

Figure 4. Retrieved sample of grade IV and V granite at G site.

Table 1. Applied chemical weathering indices. $\uparrow:$ increase, $\downarrow$ : decrease.

\begin{tabular}{ccc}
\hline Chemical Weathering Index & Equation & $\begin{array}{c}\text { Ideal Tendency with Degree of } \\
\text { Weathering }\end{array}$ \\
\hline Vogt's Ratio, VR [23] & $\left(\mathrm{Al}_{2} \mathrm{O}_{3}+\mathrm{K}_{2} \mathrm{O}\right) /\left(\mathrm{MgO}+\mathrm{CaO}+\mathrm{Na}_{2} \mathrm{O}\right)$ & $\uparrow$ \\
Modified Weathering Potential Index, & $100\left(\mathrm{~K}_{2} \mathrm{O}+\mathrm{Na}_{2} \mathrm{O}+\mathrm{CaO}+\mathrm{MgO}\right) /\left(\mathrm{SiO}_{2}+\mathrm{Al}_{2} \mathrm{O}_{3}+\right.$ & $\downarrow$ \\
MWPI [24] & $\left.\mathrm{Fe}_{2} \mathrm{O}_{3}+\mathrm{FeO}+\mathrm{TiO}_{2}+\mathrm{CaO}+\mathrm{Na} \mathrm{O}_{2} \mathrm{O}+\mathrm{MgO}+\mathrm{K}_{2} \mathrm{O}\right)$ & $\uparrow$ \\
Chemical Index of Alteration, CIA [25] & $100 \mathrm{Al}_{2} \mathrm{O}_{3} /\left(\mathrm{Al}_{2} \mathrm{O}_{3}+\mathrm{CaO}+\mathrm{Na} a_{2} \mathrm{O}+\mathrm{K}_{2} \mathrm{O}\right)$ & $\uparrow$ \\
Mobiles Index, Imob [10] & $\left(\mathrm{I}_{\text {fresh }}-\mathrm{I}_{\text {weathered }}\right) / \mathrm{I}_{\text {fresh }}, \mathrm{I}=\left(\mathrm{K}_{2} \mathrm{O}+\mathrm{Na}_{2} \mathrm{O}+\mathrm{CaO}\right)$ & \\
\hline
\end{tabular}

\section{Test Results and Discussion}

\subsection{Shear Strength of Grade IV and V Granite}

The cohesion and friction angle, which are the shear strength parameters defined by the Mohr-Coulomb failure envelope, represent the shear strength of soils and rocks. However, it is known that the shear strength of grade IV and V granite dominantly depends on its friction angle because weathering results in a reduction of the cohesion. Baynes and Dearman [26] explained this tendency in their study using the failure envelopes of weathered granites and a simple model that illustrates the microfabric consequences under different degrees of weathering. They mentioned that the main factor developing cohesion is intergranular bonds and that of a friction angle is interlocking texture. When the weathering progresses severely, such as for grade IV and V granite, grain boundaries open because of microfracture, which derives a remarkable decrease of cohesion. On the other hand, since the internal weakening of the grains are small and the minerals are rarely changed, the granite maintains a high interlocking texture, resulting in a slight decrease in the friction angles. Seo et al. [27] analyzed the geotechnical properties of grade IV and V granites collected from in situ and laboratory test results performed at 17 sites in South Korea, and most of the granite showed relatively low cohesion from 0.03 to $0.09 \mathrm{MPa}$. Schnaid et al. [5] evaluated the shear strength of grade IV and V granite in Hong Kong by interpreting PMT curves, and only friction angles were used for the analysis because the cohesions measured from laboratory tests were close to zero. Therefore, in this study, it is regarded that the friction angle represents the shear strength of grade IV and V granite, 
and the friction angles $\left(\phi^{\prime}\right)$ were estimated using the relationship with limit pressure $\left(P_{L}\right)$, as shown in Equation (1), as suggested by Menard [28].

$$
P_{L}=b \times 2^{\left(\phi^{\prime}-24\right) / 4}
$$

where $P_{L}$ is the limit pressure, and $b$ is a soil condition constant: 1.8 (dry condition) and 3.5 (wet condition). The wet condition was applied because all grade IV and V granite were under the groundwater level (see Figure 2).

Figure 5 presents the distribution of the friction angles evaluated using limit pressures from the PMT at each test site, and Table 2 summarizes the maximum, average, and minimum values of the friction angles. Compared to the friction angles of grade IV and V granite in South Korea presented in a previous study by [27] $\left(30^{\circ}-55^{\circ}\right)$, the friction angles evaluated at each site seem to be appropriate; the friction angles in the present study ranged from $33.6^{\circ}$ to $52.1^{\circ}$.

Table 2. Friction angles estimated by limit pressure.

\begin{tabular}{|c|c|c|c|c|c|c|c|c|c|c|c|c|c|}
\hline \multirow{2}{*}{ Property } & \multirow{2}{*}{$\begin{array}{c}\text { Weathering } \\
\text { Grade }\end{array}$} & \multicolumn{3}{|c|}{ A Site } & \multicolumn{3}{|c|}{ G Site } & \multicolumn{3}{|c|}{ S Site } & \multicolumn{3}{|c|}{ Seo et al. [27] } \\
\hline & & Min. & Mean & Max. & Min. & Mean & Max. & Min. & Mean & Max. & Min. & Mean & Max. \\
\hline \multirow{3}{*}{$\begin{array}{c}\phi \\
\text { (deg.) }\end{array}$} & VI & 34.6 & 35.1 & 35.5 & $-*$ & 31.6 & - & 21.4 & 23.5 & 25.7 & & & \\
\hline & IV \& V & 33.6 & 37.4 & 39.4 & 35.4 & 43.3 & 52.1 & 34.3 & 37.9 & 40.1 & 30 & 33.7 & 55 \\
\hline & III & - & 40.2 & - & - & 55.8 & - & 47.4 & 49.8 & 52.3 & & & \\
\hline
\end{tabular}

* Not measured or invalid.

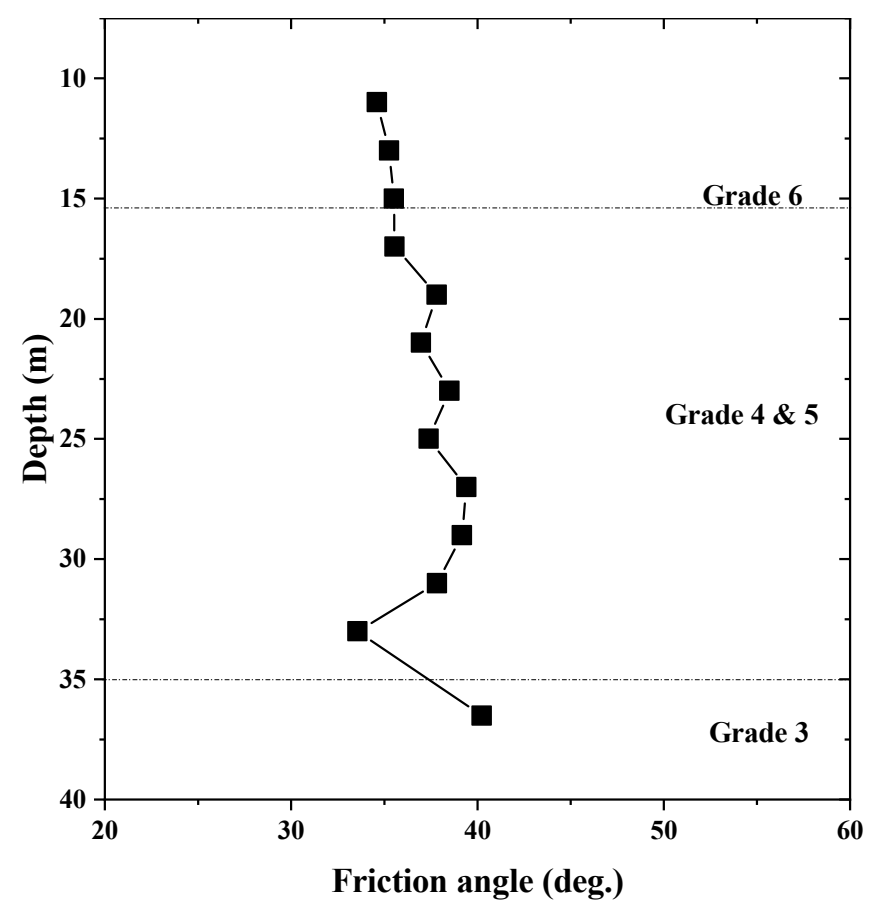

(a)

Figure 5. Cont. 


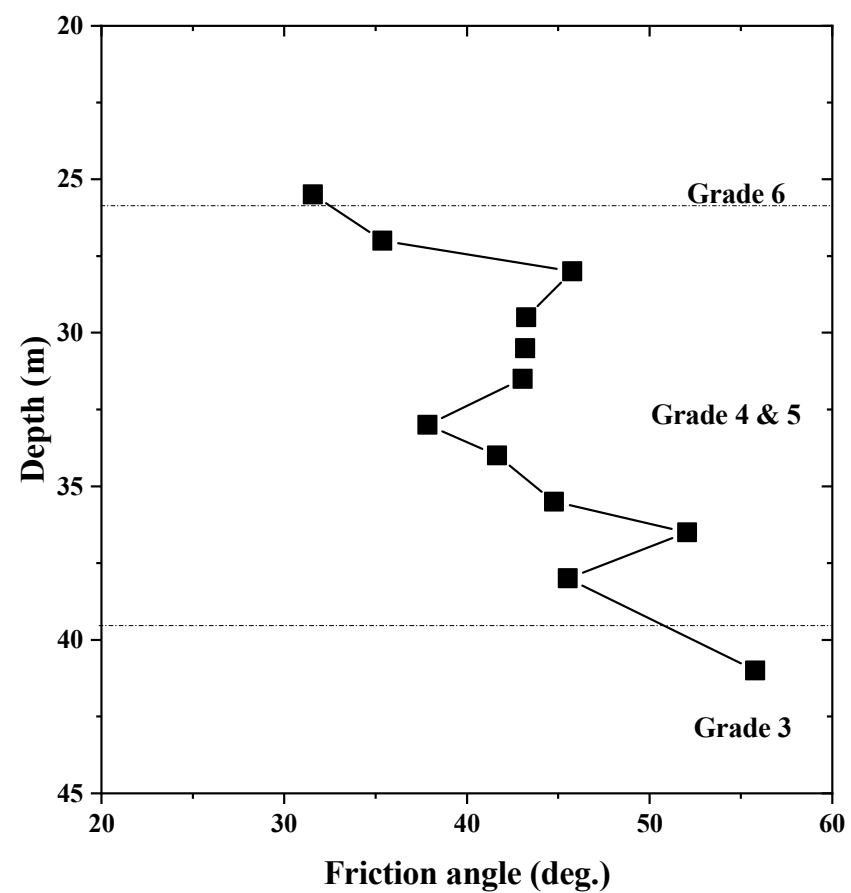

(b)

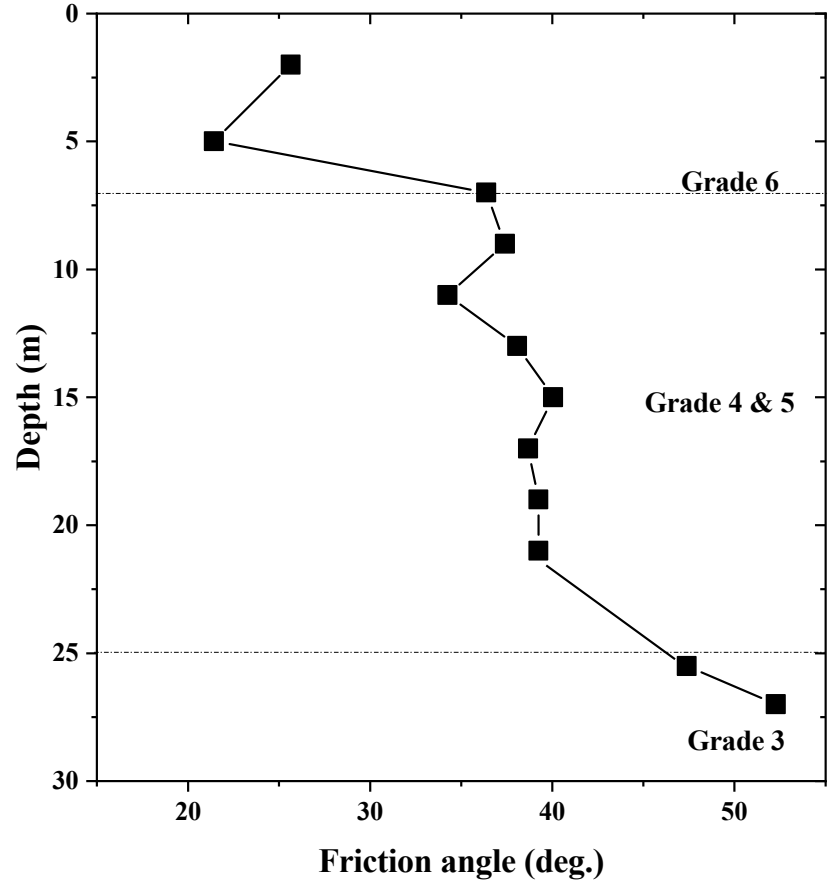

(c)

Figure 5. Distribution of friction angles: (a) A site; (b) G site; (c) S site.

It is shown that the friction angles generally increase with depth at all the test sites with minor exceptions, but the tendencies were present at a particular depth. This minor exception between friction angles and depth indicates that weathering is not linearly developed with depth, indicating that using weathering indices to estimate the weathering profile and geotechnical properties is more reasonable than using a simple model with depth. However, it is clear that the granite with the lower weathering grade has the greater friction angle.

On the other hand, friction angles at each site are in different ranges, although the weathering grades are the same; for example, the friction angle of grade VI granite at the $\mathrm{S}$ 
site is relatively lower compared with that of A and G sites, but grade III at site A shows the lowest friction angle. The possible reason for these differences is the site-specific characteristics caused by various geological factors (fracture, overburden stress, stress history, and soil particle characteristics), which are difficult to estimate in practice. Therefore, it is crucial to consider both site-specific characteristics and the degree of weathering. Based on the fact that the geotechnical properties at each test site represent the site-specific characteristics, the friction angles of grade III and VI granite developed on the upper-lower boundary of the grade IV and V granite at each site were used as input parameters to take account of the site-specific characteristics indirectly. This method can simply consider a site-specific characteristic, and the friction angle of grade III and VI granite can be reliably evaluated using laboratory tests and SPT; rock core samples of III granite for laboratory tests can be easily obtained, and the SPT is relatively acceptable to grade VI granite. The detailed procedure for considering both site-specific characteristics and the degree of weathering is presented in Section 4.3.

\subsection{Chemical Weathering Indices}

The XRF analysis for the samples retrieved from each test site was performed to estimate the weathering indices presented in Table 1. The value of a weathering index depends on the weight percentage of major oxides in the samples measured by XRF; therefore, analysis of the major oxide composition is important to select an appropriate chemical weathering index [16].

As described in Section 3.2, the composition of alkali and alkaline oxides used in the four chemical weathering indices (Vogt's Ratio (VR), Chemical Index of Alteration (CIA), Mobiles Index ( $\left.\mathrm{I}_{\mathrm{mob}}\right)$, Modified Weathering Potential Index (MWPI)) generally decreased with a change in weathering grade at each test site (Figure 6). However, the composition of $\mathrm{Na}_{2} \mathrm{O}$ and $\mathrm{K}_{2} \mathrm{O}$ did not show a consistent decreasing tendency with weathering (Table 3). In particular, the ratio of $\mathrm{K}_{2} \mathrm{O}$ increased with weathering at the $\mathrm{S}$ site. This tendency could be explained by the abundance of illite, which is a secondary clay mineral of granite. The composition of $\mathrm{K}_{2} \mathrm{O}$ is reduced because of the decomposition of K-feldspar with weathering, but the leached $\mathrm{K}$ ions are used to generate illite; therefore, the variation in $\mathrm{K}_{2} \mathrm{O}$ cannot solely represent the weathering intensity [21,29]. Therefore, it is suitable to use chemical weathering indices composed of various mobile and immobile major oxides. On the other hand, the weight percentage of $\mathrm{Fe}_{2} \mathrm{O}_{3}$ increased with weathering intensity, which is a general tendency of weathering process of granite [10,12,21,22]. The increase of $\mathrm{Fe}_{2} \mathrm{O}_{3}$ resulted from a decomposition of biotite, whose secondary minerals are chlorite, kaolinite, halloysite, and goethite. Especially, it is well known that goethite causes a partial cementation of clayey matrix in the groundwater fluctuation zone. However, since the weathered granite at all test sites in the presented study were more than $5 \mathrm{~m}$ below the groundwater level, the goethite effect on the increase of friction angle might be insignificant. Even though the goethite was generated by weathering, the majority of the secondary minerals might result in the decrease of friction angle. Baynes et al. [26] reported that kaolinite, which is a main secondary mineral of granite, surrounds the origin grains of granite and causes microfracture of the rock texture, which results in the decrease of friction angle. 


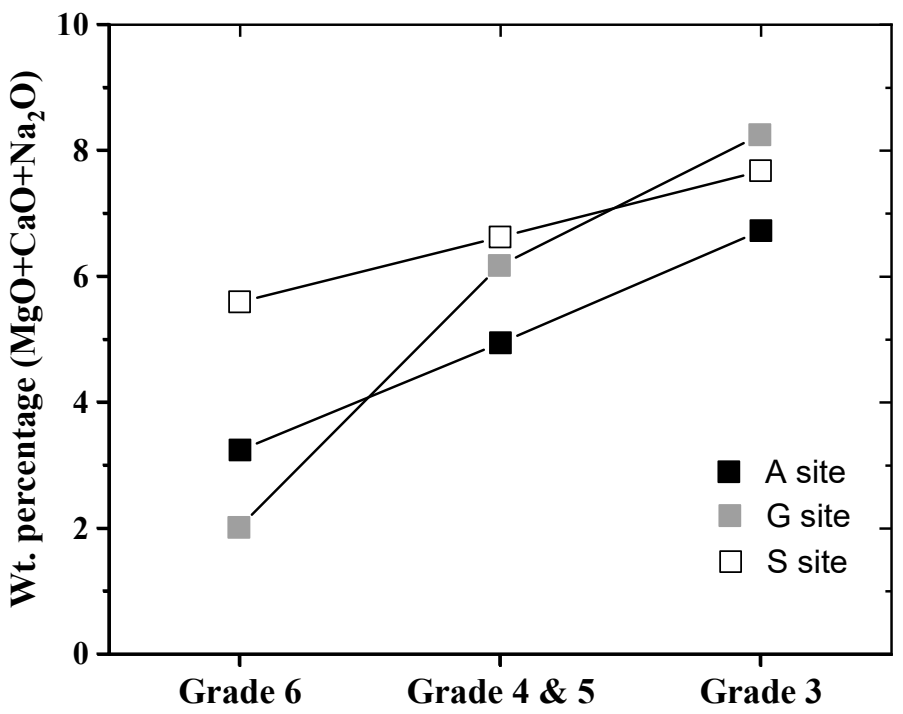

(a)

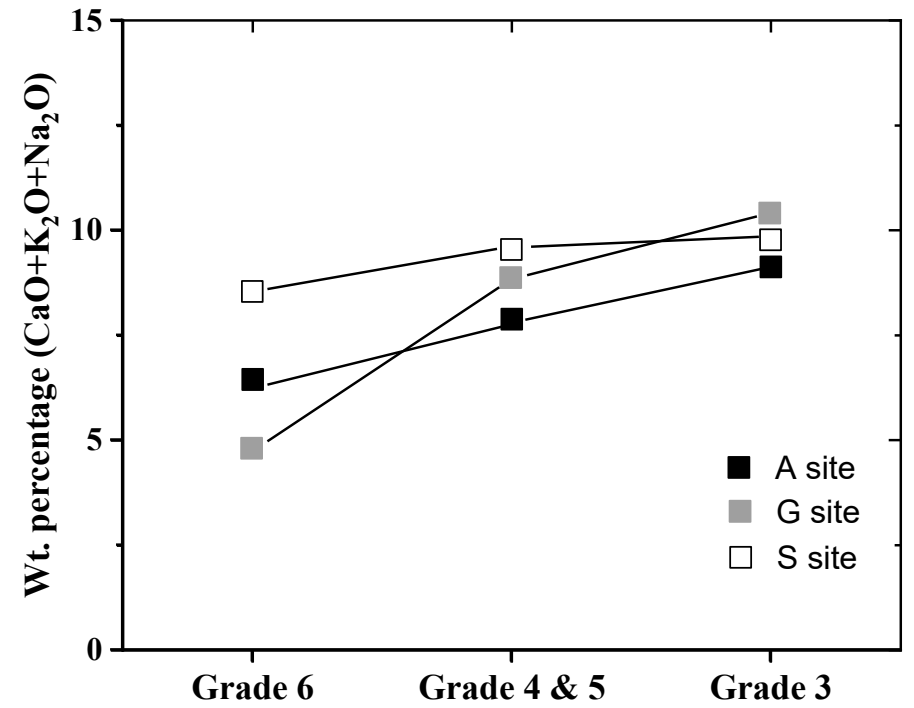

(b)

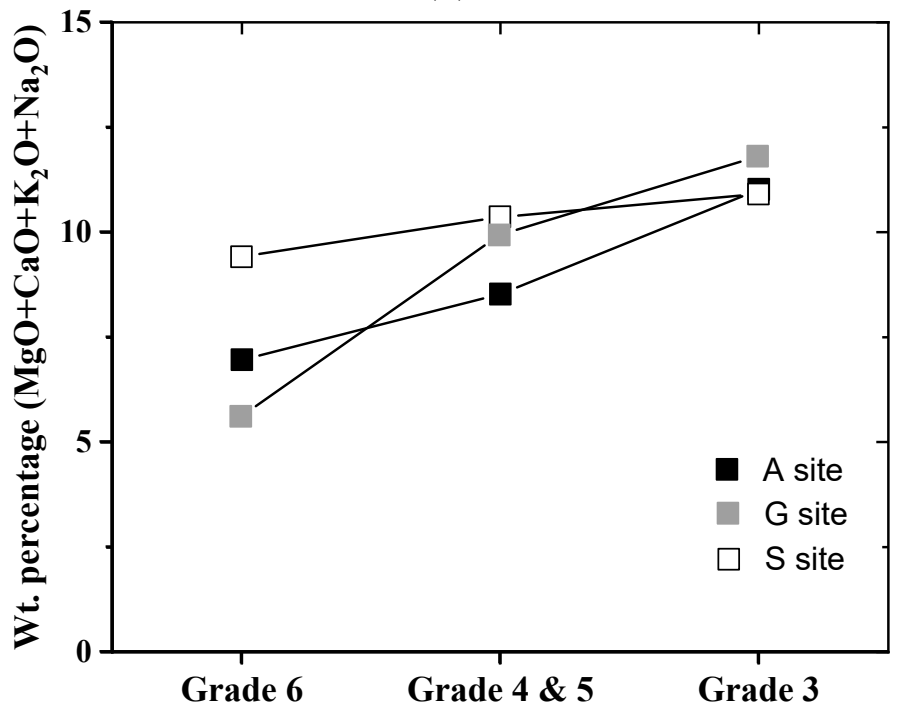

(c)

Figure 6. Weight percentage of the alkalis and alkaline oxides: (a) used in Vogt's Ratio (VR); (b) used in Chemical Index of Alteration (CIA) and Mobiles Index ( $\left.\mathrm{I}_{\mathrm{mob}}\right)$; (c) used in Modified Weathering Potential Index (MWPI). 
Table 3. Average weight percentage of major oxide.

\begin{tabular}{|c|c|c|c|c|c|c|c|c|c|c|c|c|}
\hline \multirow{2}{*}{ Test Site } & \multirow{2}{*}{$\begin{array}{c}\text { Weathering } \\
\text { Grade }\end{array}$} & \multicolumn{11}{|c|}{ Weight Percentage of Major Oxide } \\
\hline & & $\mathrm{SiO}_{2}$ & $\mathrm{Al}_{2} \mathrm{O}_{3}$ & $\mathrm{TiO}_{2}$ & $\mathrm{Fe}_{2} \mathrm{O}_{3}$ & $\mathrm{MgO}$ & $\mathrm{CaO}$ & $\mathrm{Na}_{2} \mathrm{O}$ & $\mathrm{K}_{2} \mathrm{O}$ & $\mathrm{MnO}$ & $\mathrm{P}_{2} \mathrm{O}_{5}$ & Loss on Ignition \\
\hline \multirow{3}{*}{$\begin{array}{c}\text { A } \\
\text { site }\end{array}$} & VI & 67.24 & 16.81 & 0.62 & 3.84 & 0.51 & 0.65 & 2.08 & 3.71 & 0.05 & 0.24 & 4.22 \\
\hline & IV and $\mathrm{V}$ & 68.51 & 15.75 & 0.57 & 3.48 & 0.64 & 0.83 & 3.28 & 3.76 & 0.05 & 0.20 & 2.91 \\
\hline & III & 62.58 & 15.81 & 0.54 & 3.98 & 1.89 & 2.63 & 2.2 & 4.29 & 0.05 & 0.16 & 5.85 \\
\hline \multirow{3}{*}{$\begin{array}{c}\mathrm{G} \\
\text { site }\end{array}$} & VI & 72.82 & 11.58 & 0.33 & 6.58 & 0.80 & 0.46 & 0.74 & 3.59 & 0.36 & 0.08 & 2.65 \\
\hline & IV and V & 68.09 & 15.66 & 0.43 & 3.78 & 1.06 & 1.70 & 3.40 & 3.75 & 0.06 & 0.18 & 1.83 \\
\hline & III & 66.89 & 15.94 & 0.45 & 3.69 & 1.40 & 3.32 & 3.52 & 3.55 & 0.06 & 0.17 & 0.82 \\
\hline \multirow{3}{*}{$\begin{array}{c}\mathrm{S} \\
\text { site }\end{array}$} & VI & 66.45 & 16.17 & 0.56 & 3.69 & 0.88 & 1.58 & 3.16 & 3.82 & 0.06 & 0.19 & 3.46 \\
\hline & IV and V & 67.89 & 15.40 & 0.50 & 3.22 & 0.82 & 1.74 & 4.08 & 3.74 & 0.04 & 0.17 & 2.38 \\
\hline & III & 67.54 & 15.10 & 0.52 & 3.51 & 1.15 & 2.84 & 3.72 & 3.23 & 0.05 & 0.15 & 2.22 \\
\hline
\end{tabular}

The detection limit of XRF device used in this study $10 \mathrm{ppm}$.

The average values of the chemical weathering indices evaluated in the present study are summarized in Table 4. Each index showed a distinctive tendency with weathering grade presented in Table 2 (i.e., increase or decrease); the indices defined as the molecular ratio of relatively immobile oxide to alkali and alkaline oxide (VR, CIA, Imob) increased. On the other hand, the MWPI value decreased because of the mobile oxides used as the numerator.

Table 4. Average chemical weathering index.

\begin{tabular}{|c|c|c|c|c|c|}
\hline \multirow{2}{*}{ Test Site } & \multirow{2}{*}{$\begin{array}{l}\text { Weathering } \\
\text { Grade }\end{array}$} & \multicolumn{4}{|c|}{ Chemical Weathering Index } \\
\hline & & VR & MWPI & CIA & $\mathbf{I}_{\mathrm{mob}}$ \\
\hline \multirow{3}{*}{$\begin{array}{c}\text { A } \\
\text { site }\end{array}$} & VI & 3.53 & 6.93 & 66.09 & 0.35 \\
\hline & IV and $\mathrm{V}$ & 2.37 & 8.59 & 59.01 & 0.17 \\
\hline & III & 1.55 & 12.53 & 54.78 & 0.01 \\
\hline \multirow{3}{*}{$\begin{array}{c}\mathrm{G} \\
\text { site }\end{array}$} & VI & 3.79 & 5.41 & 66.09 & 0.62 \\
\hline & IV and V & 1.77 & 10.35 & 55.27 & 0.19 \\
\hline & III & 1.29 & 12.73 & 50.43 & 0.00 \\
\hline \multirow{3}{*}{$\begin{array}{c}\mathrm{S} \\
\text { site }\end{array}$} & VI & 1.99 & 9.88 & 57.03 & 0.24 \\
\hline & IV and V & 1.65 & 10.76 & 52.53 & 0.13 \\
\hline & III & 1.32 & 11.80 & 50.60 & 0.08 \\
\hline
\end{tabular}

Figure 7 shows the distribution of normalized chemical weathering indices with depth at each test site. All of the indices showed an overall tendency with depth (VR, CIA, and $\mathrm{I}_{\text {mob }}$ are decreasing, MWPI is increasing); however, in spite of a deeper depth, the opposite tendency indicating a more weathered state was shown at a particular range. Price and Velbel [22] found a similar weathering profile within their study, and they also considered that the chemical weathering indices used in their study still presented an appropriate tendency (i.e., ideal tendency). 


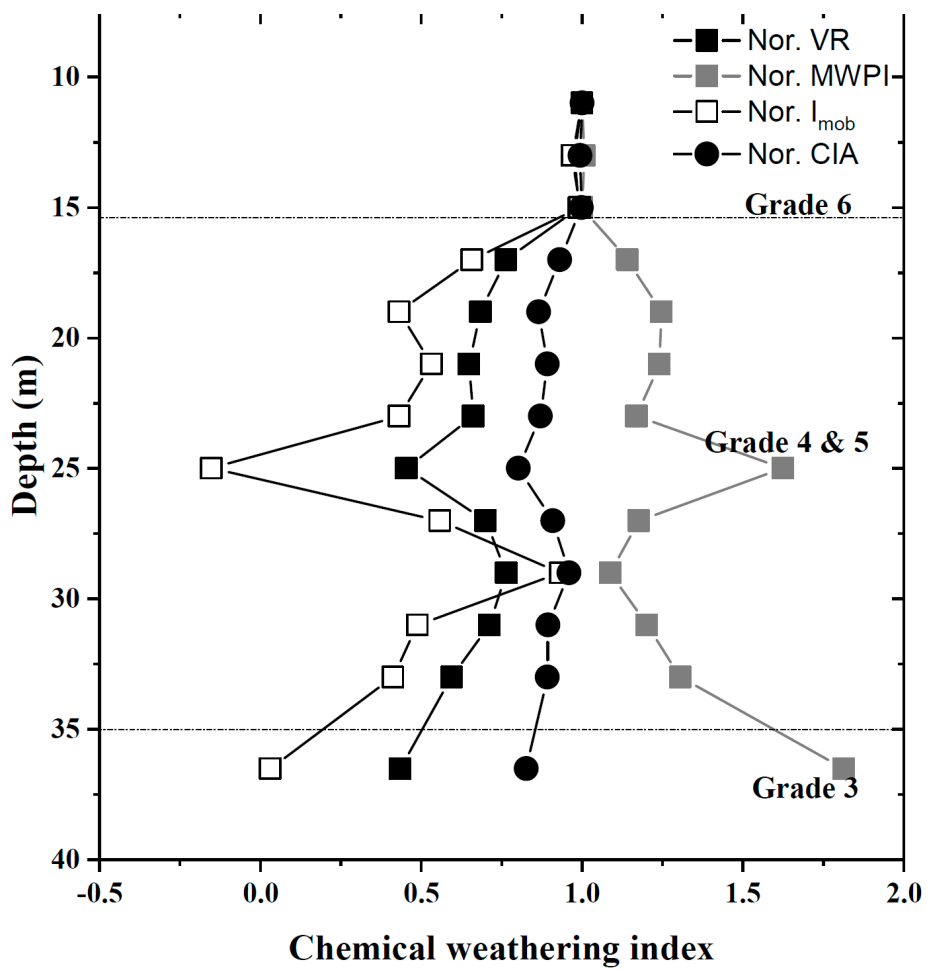

(a)

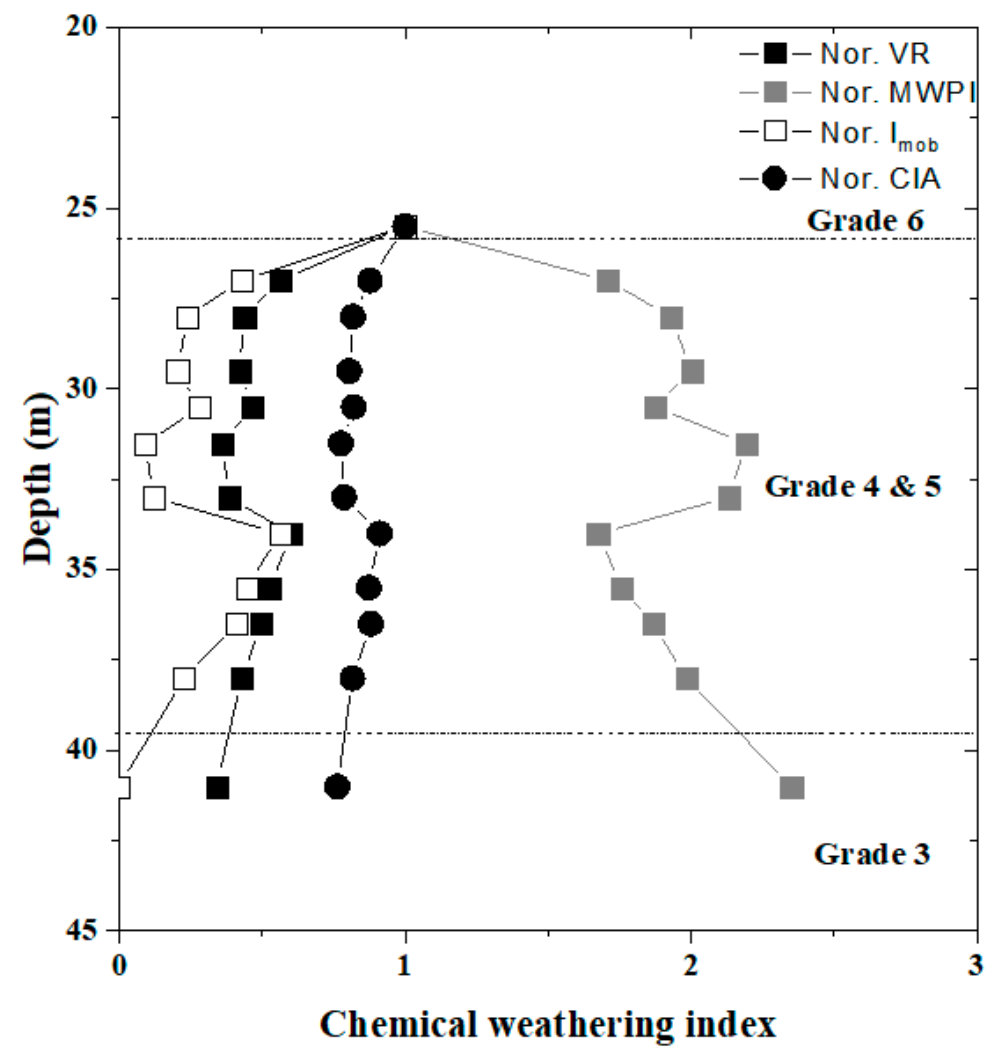

(b)

Figure 7. Cont. 


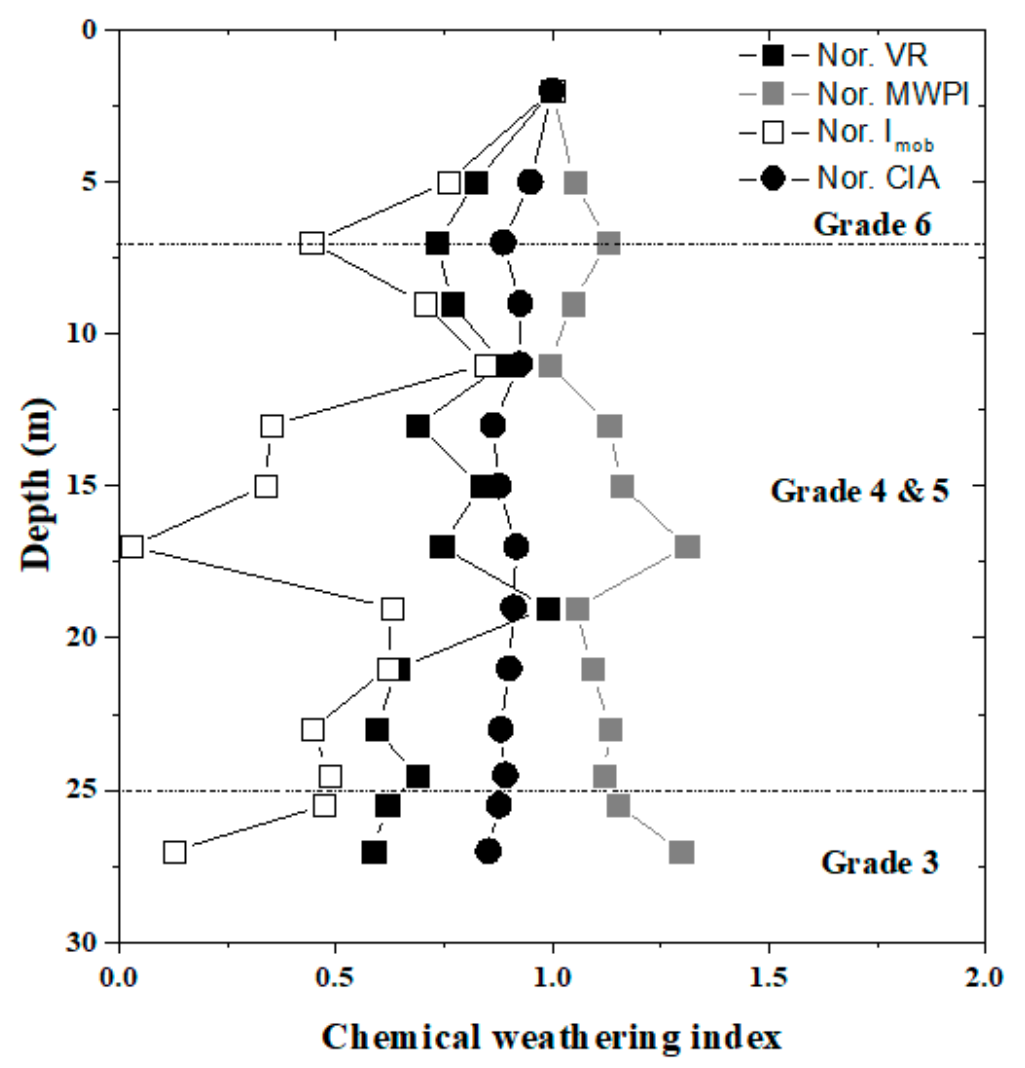

(c)

Figure 7. Distribution of normalized chemical weathering indices: (a) A site; (b) G site; (c) S site.

\subsection{Correlation Analysis}

Correlation analysis was performed to determine the relationship between the chemical weathering indices and the friction angles estimated using limit pressures. As described in Section 4.1, the weathering intensity and site-specific characteristics affect the friction angles of grade IV and V granite. Considering the effects of weathering and site-specific characteristics, the chemical weathering indices evaluated in the present study and the friction angles of grades III and IV are used as parameters determining the relationship, as suggested by Lee et al. [16,30]. Following [16,30], the presented study built correlations between the friction angle and weathering indices based on three assumptions:

(1) The friction angles of grade III and IV granite represent site-specific characteristics.

(2) The friction angles of grade III and IV granite affect those of grade IV and V granite.

(3) The friction angles of grade III and IV granite vary with the degree of weathering, which the chemical weathering indices quantitatively represent.

In this study, the suggested relationship was used to determine the relationship between the friction angles of grade IV and V granite and chemical weathering indices (Equations (2) and (3)).

$$
\begin{gathered}
\phi_{H W \& C W}=\left(\frac{W I_{M W}-W I_{H W \& C W}}{W I_{M W}-W I_{R S}}\right)^{k} \phi_{R S}+\left\{1-\left(\frac{W I_{M W}-W I_{H W \& C W}}{W I_{M W}-W I_{R S}}\right)^{k}\right\} \phi_{M W} \\
\left(\frac{\phi_{M W}-\phi_{H W \& C W}}{\phi_{M W}-\phi_{R S}}\right)=\left(\frac{W I_{M W}-W I_{H W \& C W}}{W I_{M W}-W I_{R S}}\right)^{k} \Rightarrow R_{\phi}=\left(R_{W}\right)^{k}
\end{gathered}
$$

The subscripts $M W, H W, C W$, and $R S$ refer to grade III, IV, V, and VI granite, respectively, and WI is the chemical weathering index used in the analysis. $R_{\phi}$ and $R_{W}$ are the normalized friction angles and weathering indices, respectively, and $k$ is a curve-fitting 
parameter defining the relationship between $R_{\phi}$ and $R_{W}$. The chemical weathering index of grade III and VI granite (i.e., $W I_{M W}$ and $W I_{R S}$ ) and the friction angle of grade III and VI granite (i.e., $\phi_{M W}, \phi_{R S}$ ) are boundary conditions of weathering and friction angles. Therefore, the curve-fitting parameter $k$ values for each chemical weathering index can be obtained using given sets of friction angles and weathering indices for grade IV and $V$ granite. The curve-fitting parameter $k$, which defines the best-fit curve between the friction angle and weathering index, are presented in Table 5 . The coefficient of determination $\left(R^{2}\right)$, except for the case of MWPI, was larger than 0.5, which is a moderate correlation [15]. The coefficient of determination was not so great; however, considering the high variability of geotechnical properties, it is acceptable and within values presented by previous research studies [13-15,22]. Table 5 implies that the simple estimation of the friction angle using chemical weathering indices is possible for the weathered granite for which SPT is not feasible.

Table 5. Curve-fitting parameter.

\begin{tabular}{ccccc}
\hline \multirow{2}{*}{$\begin{array}{c}\text { Weathering } \\
\text { Grade }\end{array}$} & VR & MWPI & CIA & $\mathbf{I}_{\text {mob }}$ \\
\cline { 2 - 5 } & 0.722 & 0.941 & 0.619 & 0.675 \\
\hline$k$ & 0.58 & 0.45 & 0.66 & 0.57 \\
\hline$R^{2}$ & &
\end{tabular}

The friction angles of grade IV and V granite were also predicted using Equation (2) and compared with the measured value. As shown in Figure 8, the predicted friction angles were generally closed to the measured ones, although some particular values were over- or underestimated. In particular, data of the $G$ site are relatively more scattered than those of the other sites. It is because that the measured friction angles from 29 to $33 \mathrm{~m}$ seem to be a median value, but the CIA values in that range of depth showed a similar value of grade III granite. However, since grade IV and V granite have a much larger SPT-N value than 100, the present method based on the chemical weathering indices is more reasonable compared to the estimation of the friction angle based on the SPT-N value, which is generally used in practice. Several equations estimating the friction angles based on the correlation with SPT-N values are presented in Table 6, and the measured friction angles in this study are plotted in Figure 9 with the equations. As shown in Figure 9, the measured friction angles of grade IV and $\mathrm{V}$ granite are distributed below the friction angles calculated by the previously suggested equations, and they are rarely found to have a specific correlation with the SPT-N value. Therefore, it is expected that the present method can appropriately predict the friction of grade IV and V granite, whose friction angle is hard to evaluate with SPT-N values.

Table 6. Summary of equations correlating the friction angle to the corrected standard penetration test (SPT)-N value [31].

\begin{tabular}{cc}
\hline Reference & Correlation Equation \\
\hline $\begin{array}{c}\text { Peck, Hanson, and Thornburn (PHT) (1974) } \\
\text { as mentioned in Kulhawy and Mayne (1990) }\end{array}$ & $\phi=54-27.6034 \times \exp \left(-0.014\left(N_{1}\right)_{60}\right)$ \\
\hline Hatanaka and Uchida (1996) & $\phi=27.1+0.3\left(N_{1}\right)_{60}-0.00054\left(N_{1}\right)_{60}^{2}$ \\
\hline PHT (1974) & $\phi=\sqrt{20\left(N_{1}\right)_{60}}+20$ for 3.5 $\leq\left(N_{1}\right)_{60} \leq 30$ \\
\hline Mayne et al. (2001) based on data from Hatanaka and Uchida (1996) & $\phi \overline{15.4\left(N_{1}\right)_{60}}+20$ \\
\hline Specifications for Highway Bridges (SHB) & $\phi=\sqrt{15\left(N_{1}\right)_{60}}+15$ for $\left(N_{1}\right)_{60}>5$ and $\phi \leq 45^{\circ}$
\end{tabular}




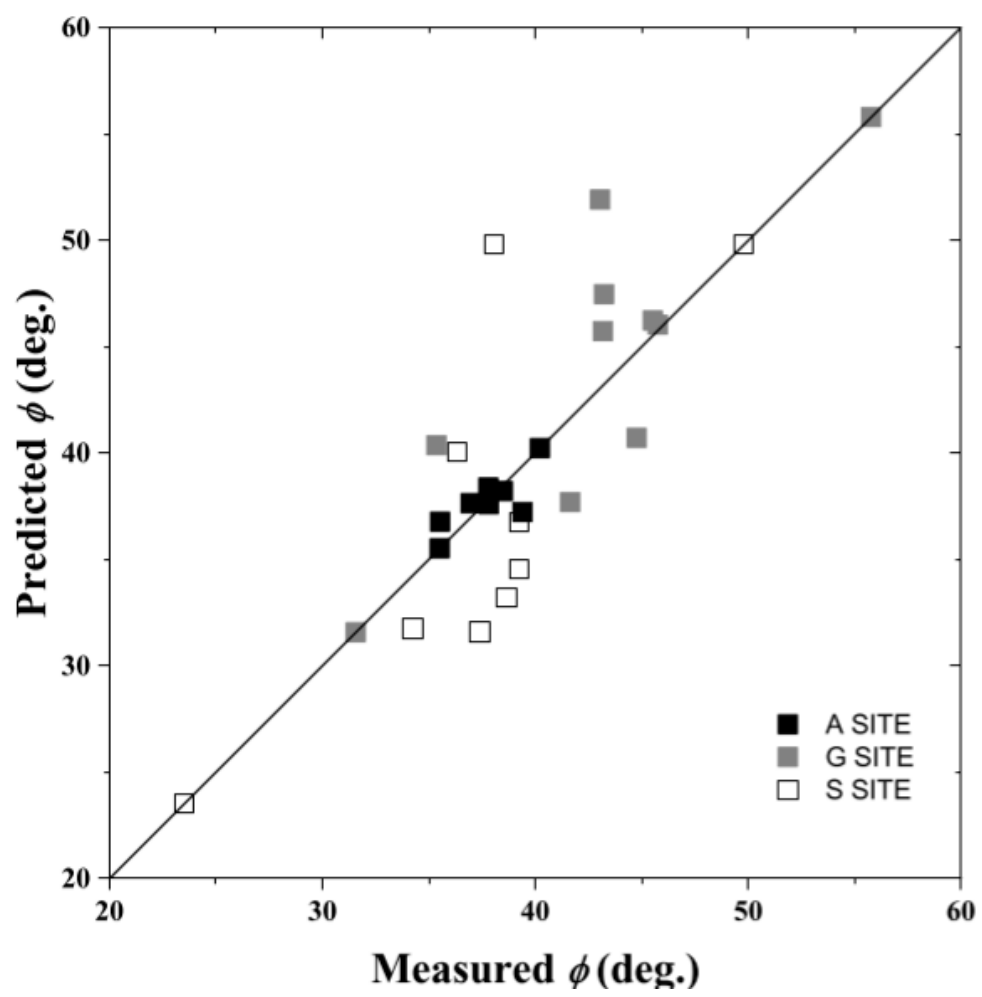

(a)

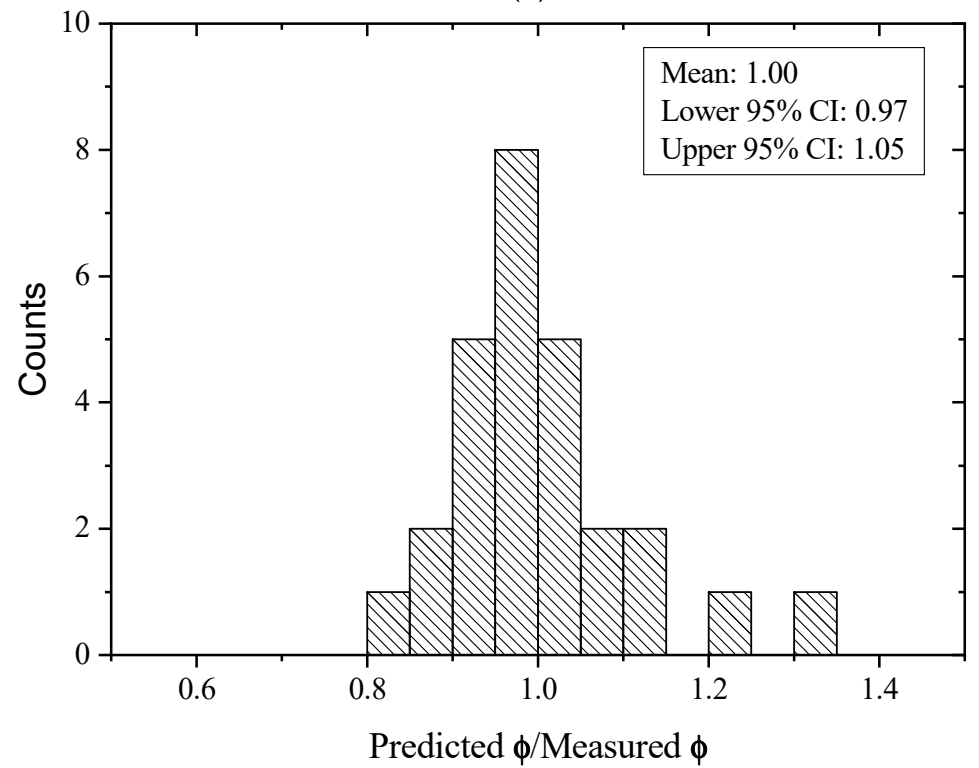

(b)

Figure 8. (a) Predicted friction angle with measured friction angle; (b) histogram of the predicted friction angle over measured friction angle. 


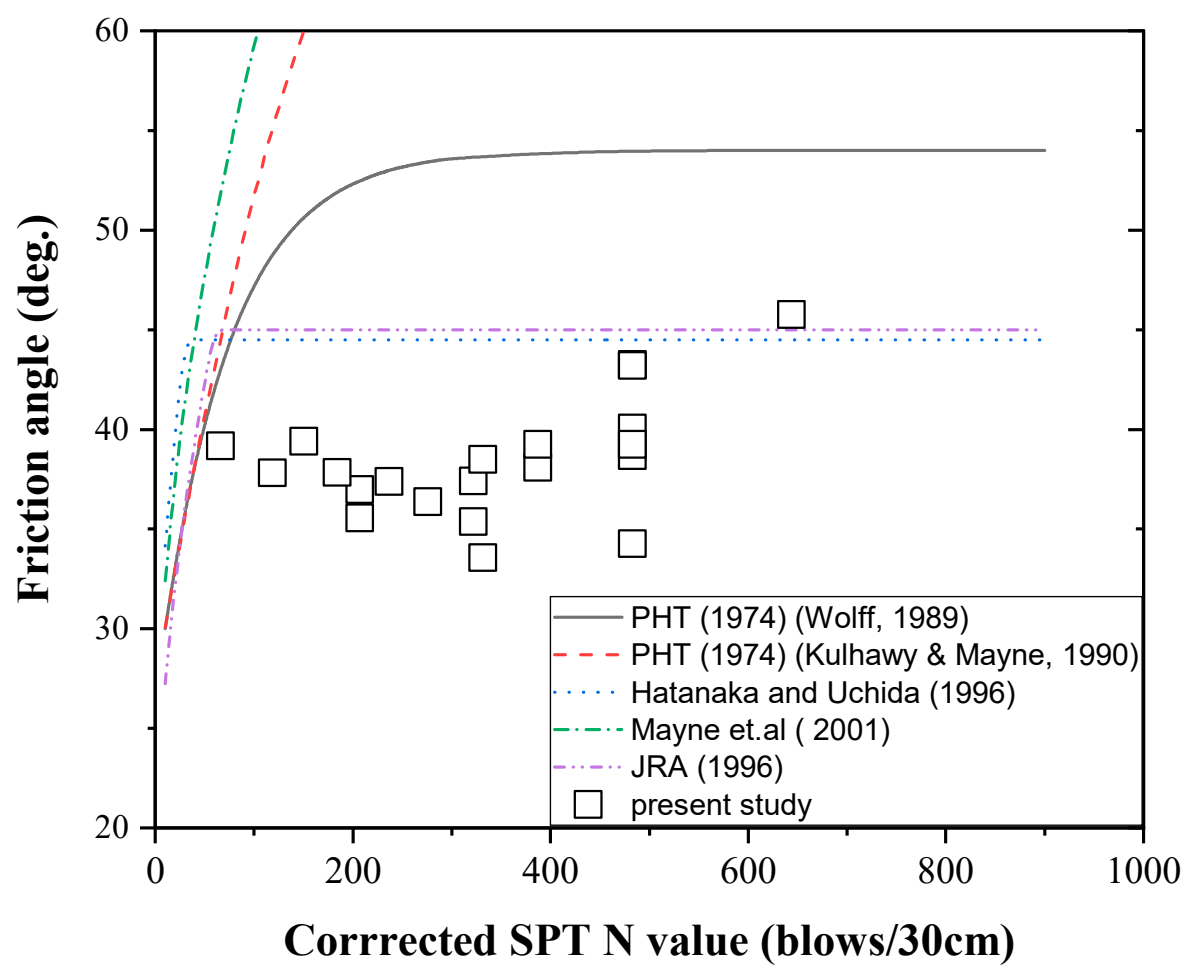

Figure 9. Comparison of friction angle with previously suggested correlation using the standard penetration test (SPT)-N value.

\section{Conclusions}

The shear strength parameters of grades IV and V granite, whose friction angles are hard to evaluate with SPT-N values, were evaluated using chemical weathering indices. The shear strength parameters were measured by interpreting the results of PMTs performed at the three test sites in which the grade IV and V granite were deeply developed. The four chemical weathering indices (i.e., VR, CIA, $\mathrm{I}_{\mathrm{mob}}$, and MWPI) were estimated by $\mathrm{XRF}$, and the relationship predicting the friction angles of grades IV and $\mathrm{V}$ granite were suggested based on the weathering indices. The conclusions of this study are as follows:

(1) By interpreting the results of PMTs, the evaluated friction angles of grade IV and V granite in the test sites are estimated from $33.6^{\circ}$ to $52.1^{\circ}$, which is acceptable to the previous studies. However, the friction angles in the particular range decreased with depth, which was different from the general tendency. The weathering profile with depth was studied based on the chemical weathering indices, and the friction angles of grade IV and V granite were evaluated by considering the weathering effect and site-specific characteristics.

(2) The weight percentage of alkaline oxides showed a distinct decrease with weathering intensity; however, the alkali oxides did not show a consistent decreasing tendency with weathering intensity. Especially, the composition of $\mathrm{K}_{2} \mathrm{O}$ was reduced because of the decomposition of $\mathrm{K}$-feldspar with weathering, but the leached $\mathrm{K}$ ions are used to generate illite.

(3) The composition of alkali and alkaline oxides used in the four chemical weathering indices (VR, CIA, $\mathrm{I}_{\mathrm{mob}}$, MWPI) was consistently decreased with the change in weathering grade at each test site, so the VR, CIA, $\mathrm{I}_{\mathrm{mob}}$, and MWPI has a typical tendency with weathering and can represent the weathering state of grade IV and V granite.

(4) Correlation analysis, including the effect of weathering and site-specific characteristics, was performed to determine the relationship between the chemical weathering indices and friction. The VR, CIA, and $\mathrm{I}_{\text {mob }}$ have a moderate correlation $\left(\mathrm{R}^{2}>0.5\right)$. Considering the natural variation of the geotechnical properties, the coefficient of determination is acceptable. The highlight of the present study is the simple method 
to estimate the friction angle of weathered granite for preliminary site investigation, which is more reliable than the SPT.

Author Contributions: Conceptualization, S.-I.W. and S.-H.L.; Methodology, C.-K.C. and Y.-W.S.; Validation, C.-K.C.; Formal Analysis, S.-H.L.; Investigation, S.-H.L. and Y.-W.S.; Writing-original draft, S.-H.L. and Y.-W.S.; Writing-review \& editing, Y.-W.S.; Funding acquisition, C.-K.C.; Project administration, Y.-W.S. All authors have read and agreed to the published version of the manuscript.

Funding: This research was supported by a grant (21SCIP-B119958-06) from the Smart Civil Infrastructure Research Program funded by the Ministry of Land, Infrastructure and Transport of the Korean government. This research was also supported by the Institute of Construction and Environmental Engineering at Seoul National University. The authors wish to express their gratitude for the support.

Institutional Review Board Statement: Not applicable.

Informed Consent Statement: Not applicable.

Data Availability Statement: The data presented in this study are available in article.

Conflicts of Interest: The authors declare no conflict of interest.

\section{References}

1. Geotechnical Control Office (GCO). Geoguide 3 Guide to Rock and Soil Descriptions; The Government of the Hong Kong Special Administrative Region: Hong Kong, 2017. Available online: https:/ /www.cedd.gov.hk/eng/publications/geo/geoguides/geog3/index.html (accessed on 13 November 2020).

2. Kanji, M.A. Critical issues in soft rocks. J. Rock Mech. Geotech. Eng. 2014, 6, 186-195. [CrossRef]

3. Benoît, J.; Howie, J.A. A View of Pressuremeter Testing in North America. Soils Rocks 2014, 37, $211-231$.

4. Lee, S.-H.; Baek, S.; Song, Y.-W.; Chung, C.-K. Case Study of Correlation between the SPT- N Value and PMT Results Performed on Weathered Granite Zone in Korea. J. Korean Geotech. Soc. 2019, 35, 15-24.

5. Schnaid, F.; Ortigao, J.A.R.; Mantaras, F.M.; Cunha, R.P.; MacGregor, I. Analysis of self-boring pressuremeter (SBPM) and Marchetti dilatometer (DMT) tests in granite saprolites. Can. Geotech. J. 2000, 37, 796-810. [CrossRef]

6. Jacobs, S.A. Insitu Measurement of Florida Limestone Modulus and Strength Properties. Ph.D. Thesis, University of Florida, Gainesville, FL, USA, 2003.

7. Dafni, J. The Analysis of Weak Rock Using the Pressuremeter. Ph.D. Thesis, University of Washington, Seattle, WA, USA, 2013.

8. Clarke, B.G.; Smith, A. Self-boring pressuremeter tests in weak rocks. Constr. Build. Mater. 1992, 6, 91-96. [CrossRef]

9. Bustamante, M.; Gambin, M.; Gianeselli, L. Pile Design at Failure Using the Ménard Pressuremeter: An Up-Date. In Proceedings of the International Foundation Congress \& Equipment Expo ‘09, ASCE Geotechnical Special Publication No. 186, Orlando, FL, USA, 15-19 March 2009; pp. 127-134.

10. Irfan, T.Y. Mineralogy, fabric properties and classification of weathered granites in Hong Kong. Q. J. Eng. Geol. Hydrogeol. 1996, 29, 5-35. [CrossRef]

11. Arel, E.; Tugrul, A. Weathering and its relation to geomechanical properties of Cavusbasi granitic rocks in Northwestern Turkey. Bull. Eng. Geol. Environ. 2001, 60, 123-133. [CrossRef]

12. Chiu, C.F.; $\mathrm{Ng}, \mathrm{C} . \mathrm{W} . \mathrm{W}$. Relationships between chemical weathering indices and physical and mechanical properties of decomposed granite. Eng. Geol. 2014, 179, 76-89. [CrossRef]

13. Kim, S.; Park, H.-D. The relationship between physical and chemical weathering indices of granites around Seoul, Korea. Bull. Eng. Geol. Environ. 2003, 62, 207-212. [CrossRef]

14. Udagedara, D.T.; Oguchi, C.T.; Gunatilake, A.A.J.K. Combination of chemical indices and physical properties in the assessment of weathering grades of sillimanite-garnet gneiss in tropical environment. Bull. Eng. Geol. Environ. 2017, 76, 145-157. [CrossRef]

15. Rigopoulos, I.; Tsikouras, B.; Pomonis, P.; Hatzipanagiotou, K. Assessment of the engineering behavior of ultramafic and mafic rocks using chemical indices. Eng. Geol. 2015. [CrossRef]

16. Lee, S.-H.; Baek, S.-H.; Woo, S.I.; Chung, C.-K. Estimation of in situ geotechnical properties on highly weathered granite using chemical weathering indices. Bull. Eng. Geol. Environ. 2020. [CrossRef]

17. ASTM D1586. Standard Test Method for Standard Penetration Test (SPT) and Split-Barrel Sampling of Soils; American Society for Testing and Materials: West Conshohocken, PA, USA, 2011. [CrossRef]

18. Seoul Metropolitan Corporation. Site Investigation Manual; Seoul Metropolitan Government: Seoul, Korea, 2006.

19. ASTM D4719. Standard Test Methods for Prebored Pressuremeter Testing in Soils; American Society for Testing and Materials: West Conshohocken, PA, USA, 2007.

20. Gupta, A.S.; Rao, K.S. Weathering indices and their applicability for crystalline rocks. Bull. Eng. Geol. Environ. 2001, 60, 201-221. [CrossRef] 
21. Duzgoren-Aydin, N.; Aydin, A.; Malpas, J. Re-assessment of chemical weathering indices: Case study on pyroclastic rocks of Hong Kong. Eng. Geol. 2002, 63, 99-119. [CrossRef]

22. Price, J.R.; Velbel, M.A. Chemical weathering indices applied to weathering profiles developed on heterogeneous felsic metamorphic parent rocks. Chem. Geol. 2003, 202,397-416. [CrossRef]

23. Vogt, T. Sulitjelmafeltets geologi og petrografi. Nor. Geo-logiske Undersokelse 1927, 121, 1-560.

24. Vogel, D.E. Precambrian Weathering in Acid Metavolcanic Rocks from the Superior Province, Villebon Township, South-Central Québec. Can. J. Earth Sci. 1975, 12, 2080-2085. [CrossRef]

25. Nesbitt, H.W.; Young, G.M. Early Proterozoic climates and plate motions inferred from major element chemistry of lutites. Nature 1982, 299, 715-717. [CrossRef]

26. Baynes, F.J.; Dearman, W.R. The relationship between the microfabric and the engineering properties of weathered granite. Bull. Int. Assoc. Eng. Geol. 1978, 18, 191-197. [CrossRef]

27. Seo, Y.-S.; Yun, H.-S.; Kim, D.-G.; Kwon, O.-I. Analysis on Physical and Mechanical Properties of Rock Mass in Korea. J. Eng. Geol. 2016, 26, 593-600. [CrossRef]

28. Menard, L. The Menard Pressuremeter: Interpretation and Application of Pressuremeter Test Results to Foundation Design. Sols Soils 1975, 26, 5-43.

29. Lee, C.; Cho, T. Effects of Rock Weathering on the Degradation of Engineering Properties. J. Korean Soc. Rock Mech. 2005, 15, 411-424.

30. Lee, S.-H. Estimation of Geotechnical Properties on Highly and Completely Weathered Granite using Chemical Weathering Index. Ph.D. Thesis, Seoul National University, Seoul, Korea, 2020.

31. Paikowsky, S.G.; Canniff, M.C.; Lesny, K.; Kisse, A.; Amatya, S.; Muganga, R. LRFD Design and Construction of Shallow Foundations for Highway Bridge Structures; Transportation Research Board: Washington, DC, USA, 2010. 